\title{
ASSESSMENT OF SPATIAL AND TEMPORAL FLUCTUATIONS IN WATER QUALITY OF A TROPICAL PERMANENT ESTUARINE SYSTEM - TAPI, WEST COAST INDIA
}

\author{
J.I. NIRMAL KUMAR ${ }^{1} *$ B. GEORGE ${ }^{1}-$ R.N. $\mathrm{KUMAR}^{2}-$ P.R. SAJISH ${ }^{1}-\mathrm{S} \mathrm{VIYOL}^{1}$ \\ ${ }^{I}$ P.G. Department of Environmental Science and Technology, Institute of Science and \\ Technology for Advanced Studies and Research (ISTAR), Vallabh Vidya Nagar, Gujarat - \\ 388120. India \\ ${ }^{2}$ Department of Biological Science and Environmental Science, N.V. Patel College of Pure and \\ Applied Science, Vallabh Vidya Nagar, Gujarat - 38 120. India \\ *Corresponding author \\ e-mail: istares2005@yahoo.com
}

(Received $28^{\text {th }}$ September 2009 ; accepted $14^{\text {th }}$ December 2009)

\begin{abstract}
A study pertaining to seasonal variation in physicochemical properties was carried out at five sites of Tapi estuarine zone for a period of one year i.e. July 2008 to June 2009. It revealed that the estuarine zone was significantly influenced by freshwater input during monsoon and post-monsoon periods. Concentration of all the nutrients and dissolved oxygen (DO) was relatively high during the monsoon, whereas, and salinity were at their minimum level during this period. Phytoplankton production peak in terms of chlorophyll-a ( $\mathrm{Chl}$ a) was observed in summer and winter during which a typical marine condition prevailed. In present study observed correlated values of salinity, nitrate, phosphate, silicate, values are significantly high in the estuarine zone. Cluster analysis carried out for both monthly and station-wise and average values gives different clusters depending on the affinity and relation between months and sites due to environmental conditions prevailed in the estuary zone. Principal Component Analysis (PCA) was used in the ordination of samples (site, season and physicochemical parameters). The PCA was performed using all variables, Eigenvalues accounts and Scree plot showed that the first three Principal Components are the most significant components which represent more than $75 \%$ of the variance in water quality parameters in Tapi estuary, $48.5 \%$ by PC1, $14.4 \%$ by PC 2 and $12.1 \%$ by PC3.

Keywords: Estuary, Dissolved nutrients, Cluster analysis, Principal Component Analysis
\end{abstract}

\section{INTRODUCTION}

Dissolved nutrients are the raw material for the marine trophic chain and estuaries are the main entry for nutrients coming from continental drainage to the marine environment $[3,16]$. The nutrient supply is greater in estuaries that are near densely populated regions, due to the entry of domestic and industrial waste, urban drainage, and agricultural effluents. The increase of nutrient concentrations in estuarine and coastal waters causes several environmental modifications, such as increases in productivity and fishing yields [18, 26, 31]. However, anthropogenic inputs frequently cause excessive eutrophication in the environment, especially where the circulation is restricted, such as in estuaries and coastal regions. Several alterations in chemical characteristics and water quality in such water bodies occur as a result of varying river flows. Such alterations can lead to various ecological consequences like changes in species composition, blooms of phytoplankton and decrease of oxygen concentrations.

Tidal variation and nutrient dynamics is more pronounced in tropical estuaries than in temperate estuaries. Reports on some tropical estuaries include those of [8] on the Kollidan estuary, southeast coast of India, [12] on the Mahi estuary and in Coastal waters of Kalpakam, East coast of India [28]. Physico chemical characteristics of 
tropical Devi Estuary in the eastern region of India was analysed by [20]. Physicochemical characteristics in relation to pollution and phytoplankton production potential of brackish water were carried out in Sundarbans of India by [30]. This paper aims to assess spatial and temporal fluctuations of water quality of Tapi estuarine system of western India.

\section{STUDY AREA}

Gulf of Khambhat on the western India has been profusely endowed with major perennial rivers like Tapi, Narmada, Mahi and many minor rivers. The Tapi River estuary is permanent tropical estuary and one of the major estuaries on the Gulf of Khambhat (Fig. 1). The estuary is located at geographical position Lat $21^{\circ} 40^{\prime} \mathrm{N}$ and Long $72^{\circ} 40^{\prime} \mathrm{E}$. Its length from source to mouth is about $720 \mathrm{~km}$ and with a catchment area of approximately $1,650,000 \mathrm{~km}^{2}$. The river originates in Madhya Pradesh state and after its course through Maharashtra, Tapi river ends in Gulf of Khambhat of the Arabian Sea. Along its course the river receives industrial effluents released from urban cities like Surat and many chemical and fertilizers industries in and around Hazira industrial area which forms the major source of pollution in to the estuary. The estuarine region experience high, semi diurnal tides with a range of $5.5 \mathrm{~m}$ at spring decreasing to $2.3 \mathrm{~m}, 25 \mathrm{~km}$ upstream and $2.3 \mathrm{~m}$ at neap going down to $0.4 \mathrm{~m}$ at a distance of $25 \mathrm{~km}$ in the estuary. Salinity intrusion is largely governed by the tidal phase and is felt up to 30 $\mathrm{km}$ upstream during the dry season. Strong tidal current exceeding $1 \mathrm{~m} / \mathrm{s}$ sweep the shallow estuary making it vertically well mixed expect during short period of tidal slacks [23].

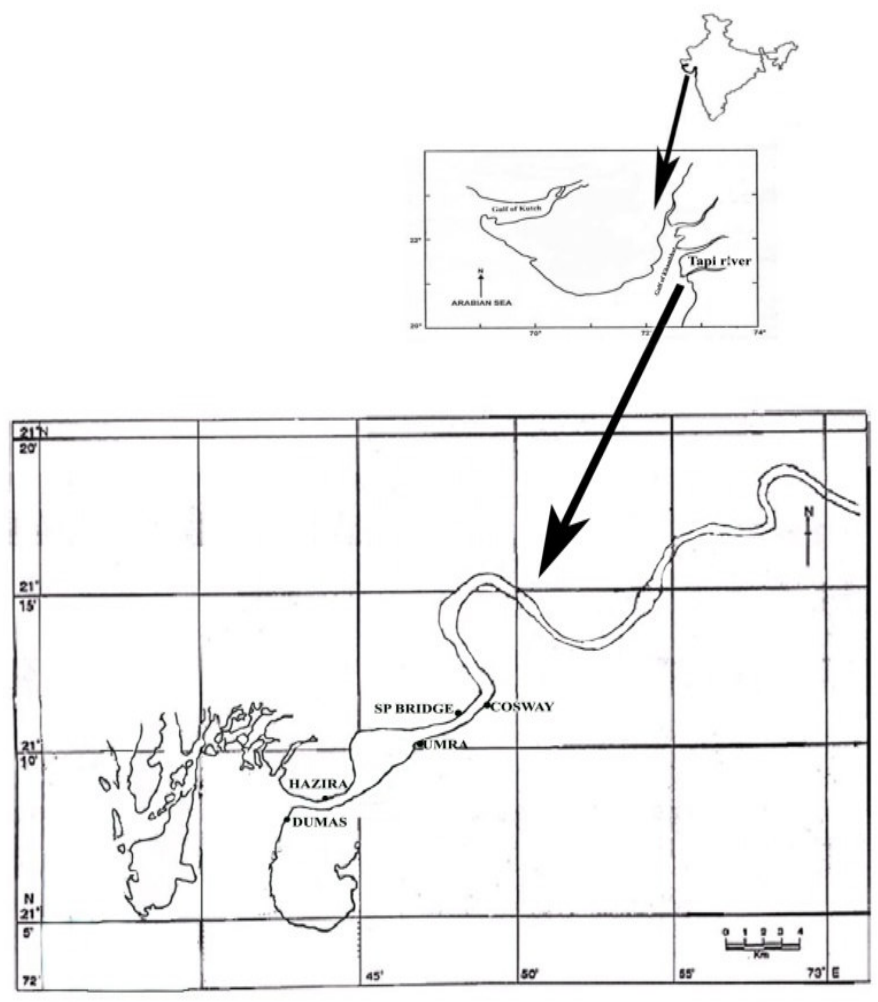

Figure 1. Study sites along the Tapi estuary region 
Five different study sites were selected on the northern and southern banks of the river. Dumas was the site selected in the mouth of the estuary in the southern bank. Hazira which forms the second study site was about $4 \mathrm{~km}$ far from the mouth and located in the northern bank. Third site selected was Umra which is $15-17 \mathrm{~km}$ away from the mouth. Fourth site which was selected is SP Bridge which is $22 \mathrm{~km}$ away from the mouth. The fifth site, Cosway was $27-29 \mathrm{~km}$ away from the mouth of estuary. A small dam built at the upstream of Cosway prevents the sea water in flux to the river and the tidal effect is influenced up to this site only.

\section{MATERIALS AND METHODS}

Water samples for physical and chemical parameters determination were collected from the river at monthly interval from July, 2008 to June 2009. The samples were collected during the time of high tide, in polyethylene bottles and brought to the laboratory. In the field its self, $\mathrm{pH}$ and DO was analysed. Dissolved oxygen was determined by the alkali-Azide modification of Winkler's technique, alkalinity was determined titrimetricall Nitrate was estimated by the cadmium reduction method. Phosphate and silica were determined by the ascorbic acid and molybdosilicate methods respectively as described by [2]. Sodium and Potassium was estimated using Flame photometer. Chlorophyll-a was estimated by filtering the sample through glass fibre filter papers and it was extracted in $90 \%$ acetone, estimated spectrophotometricaly.

\section{RESULTS AND DISCUSSION}

\section{Hydrochemistry of Tapi}

Descriptive statistics of the data is given in Table.1. The average surface water temperature of study sites varied from $23.5^{\circ} \mathrm{C}$ to $33.5^{\circ} \mathrm{C}$ (Fig. 2.a). The $\mathrm{pH}$ of water ranges from 7.2 to 8.5 where the highest recorded at SP Bridge during the dry seasons and lowest in Umra but $\mathrm{pH}$ values did not show significant fluctuation during the present study (Fig. 2.b). The extensive buffering capacity of the seawater may be the causes of change of $\mathrm{pH}$ within a very narrow limit in the present study [25]. As compared with other tropical estuaries tidal influence has a great influence on Tapi estuarine environment [23].

Table 1. Descriptive statistics of the data along the study sites of Tapi Estuary from July 2008 to June 2009

\begin{tabular}{|c|c|c|c|c|c|c|c|c|}
\hline & Mean & S.E.M & S.D. & Variance & Coff. Var. & Min & Max & $\mathbf{N}$ \\
\hline Temp $\left({ }^{\circ} \mathrm{C}\right)$ & 29.34 & 0.3761 & 2.91397 & 8.49125 & 0.09931 & 23.5 & 33.5 & 60 \\
\hline $\mathrm{pH}$ & 7.96666 & 0.0346 & 0.26849 & 0.07209 & 0.03370 & 7.2 & 8.5 & 60 \\
\hline $\mathrm{DO}\left(\mathrm{mgL}^{-1}\right)$ & 4.65966 & 0.191 & 1.48135 & 2.19441 & 0.31791 & 2.1 & 8.5 & 60 \\
\hline Sali (ppt) & 10.3443 & 1.4350 & 11.1162 & 123.570 & 1.07461 & 0.11 & 32 & 60 \\
\hline Alk $\left(\mathrm{mgL}^{-1}\right)$ & 124.05 & 2.9751 & 23.0455 & 531.099 & 0.18577 & 76 & 224 & 60 \\
\hline $\mathrm{PO}_{4}\left(\mu \mathrm{molL}^{-1}\right)$ & 2.73197 & 0.1797 & 1.39237 & 1.93871 & 0.50966 & 0.16 & 4.98 & 60 \\
\hline $\mathrm{SO}_{4}\left(\mathrm{mgL}^{-1}\right)$ & 1.24409 & 0.0941 & 0.72898 & 0.53142 & 0.58595 & 0.385 & 2.986 & 60 \\
\hline $\mathrm{K}\left(\mathrm{mgL}^{-1}\right)$ & 86.1833 & 5.8459 & 45.2827 & 2050.52 & 0.52542 & 25 & 190 & 60 \\
\hline $\mathrm{Na}\left(\mathrm{mgL}^{-1}\right)$ & 694.183 & 61.026 & 472.712 & 223456. & 0.68096 & 50 & 1495 & 60 \\
\hline $\mathrm{NO}_{3}\left(\mu \mathrm{molL}^{-1}\right)$ & 6.48933 & 0.2340 & 1.81277 & 3.28615 & 0.27934 & 3.74 & 11.6 & 60 \\
\hline $\mathrm{SiO}_{2}\left(\mu \mathrm{molL}^{-1}\right)$ & 393.8977 & 11.461 & 88.7808 & 7882.04 & 0.22539 & 181.45 & 573.94 & 60 \\
\hline Chl- $a\left(\mu \mathrm{glL}^{-1}\right)$ & 4.0992 & 0.3624 & 2.80743 & 7.88169 & 0.68487 & 0.16 & 10.2 & 60 \\
\hline
\end{tabular}


The salinity ranges from $0.11 \mathrm{ppt}$ in fresh water site Cosway during monsoon period to $32 \mathrm{ppt}$ in Dumas in the month of May (Fig. 2.c). The dry season experienced the highest salinity range $32 \pm 3$ ppt. The salinity is greatly influenced by the runoff water, so that the lowest salinity was observed during monsoon season.

The Dissolved oxygen ranges from $2.1 \mathrm{mg} \mathrm{L}^{-1}$ during the December in SP Bridge to $8.5 \mathrm{mg} \mathrm{L}^{-1}$ in Dumas during September (Fig. 2.d). The Dissolved Oxygen was found more on the lower reaches when compared to upper reaches. Dissolved Oxygen shows a negative correlation with temperature $(-0.17)$. In aquatic systems, oxygenation is the result of an imbalance between the process of photosynthesis, degradation of organic matter, re-aeration [10], and physicochemical properties of water [3]. During the present study, salinity was found to be the most important factor that controlled the level of DO in coastal waters as evident from its non-significant correlation with DO (Table 2). A positive correlation of all the nutrients, except nitrate and phosphate, with DO was also observed which showed that DO concentration in this coastal water was largely dependent on the freshwater influx. The above observation was further supported by the strong negative correlation of DO with chl- $a$, which showed that contribution of photosynthetic release of DO was negligible [28].

The alkalinity value ranges from $76 \mathrm{mg} \mathrm{L}^{-1}$ Cosway during September to $168 \mathrm{mg} \mathrm{L}^{-1}$ in Dumas in the month of August (Fig. 2.e) with a mean difference $124 \pm 23$ along the study sites. The sulphate concentration showed a clear variation from $0.385 \mathrm{mg} \mathrm{L}^{-1}$ in the fresh water receiving site, Cosway to $2.986 \mathrm{mg} \mathrm{L}^{-1}$ Hazira which is in the lower saline region (Fig. 2.f). The sulphate concentration shows a significant positive correlation with $\mathrm{pH}$, Salinity, Alkalinity where as it shows a negative correlation with Phosphate, Nitrate and Chlorophyll-a.
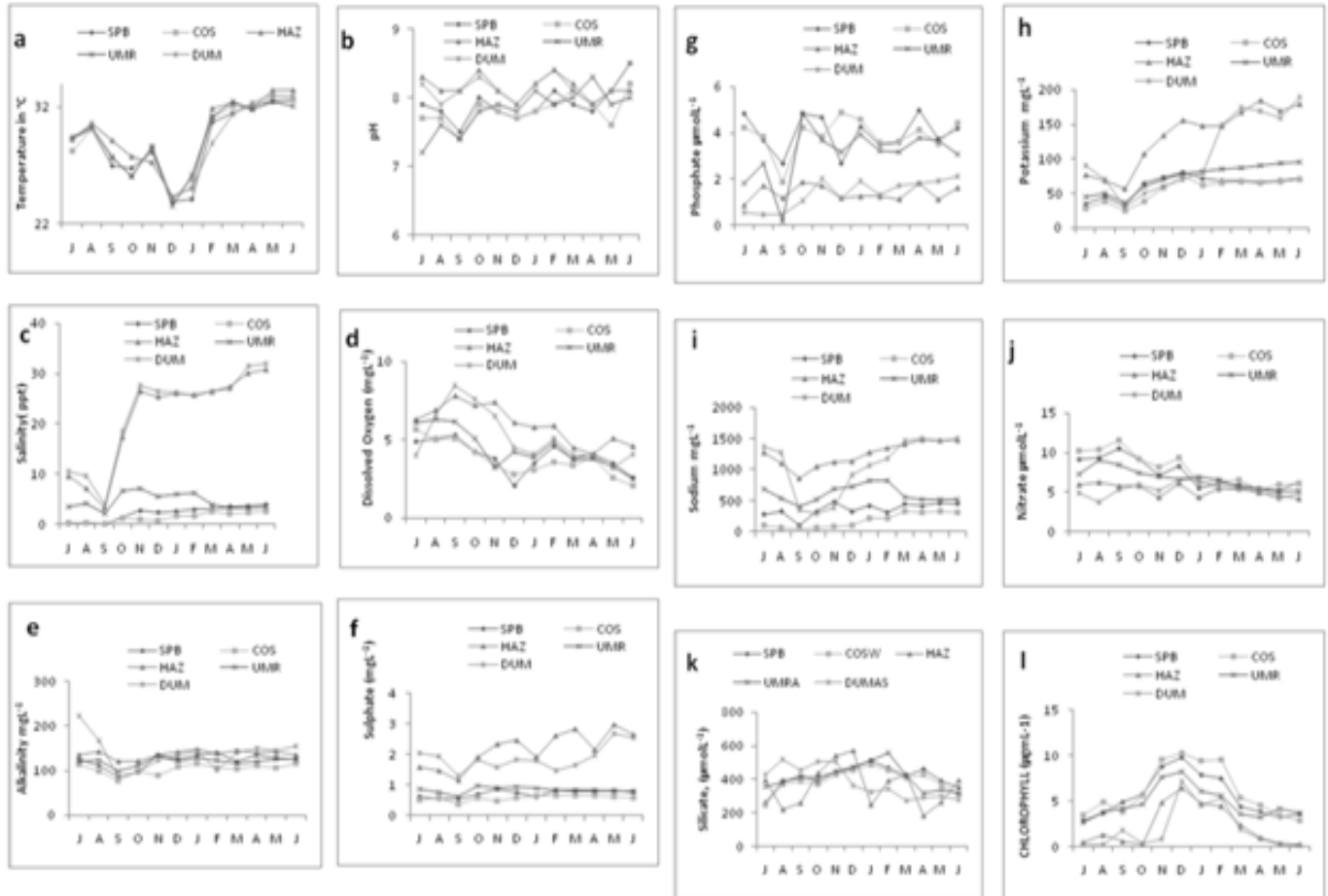

Figure 2. (a-l) Seasonal Distribution of nutrients along the study sites of Tapi Estuary from July 2008 to June 2009 
Table 2. Correlation between different physicochemical parameters along the study sites of Tapi Estuary from July 2008 to June 2009

\begin{tabular}{|c|c|c|c|c|c|c|c|c|c|c|c|c|}
\hline & ${ }^{\circ} \mathbf{C}$ & pH & Salinity & DO & Alk. & $\mathrm{SO}_{4}$ & $\mathrm{PO}_{4}$ & $\mathbf{K}$ & $\mathrm{Na}$ & $\mathrm{NO}_{3}$ & $\mathrm{SiO}_{2}$ & Chl- $a$ \\
\hline${ }^{\circ} \mathrm{C}$ & 1 & & & & & & & & & & & \\
\hline $\mathrm{pH}$ & 0.27 & 1 & & & & & & & & & & \\
\hline Sal & 0.10 & 0.50 & 1 & & & & & & & & & \\
\hline $\mathrm{DO}$ & -0.17 & 0.07 & 0.21 & 1 & & & & & & & & \\
\hline Alk. & 0.16 & 0.37 & 0.47 & -0.06 & 1 & & & & & & & \\
\hline $\mathrm{SO}_{4}$ & 0.18 & 0.53 & 0.92 & 0.32 & 0.60 & 1 & & & & & & \\
\hline $\mathrm{PO}_{4}$ & -0.03 & -0.22 & -0.62 & -0.59 & -0.33 & $\begin{array}{l}-0.69 \\
\end{array}$ & 1 & & & & & \\
\hline $\mathrm{K}$ & 0.31 & 0.49 & 0.83 & -0.09 & 0.52 & 0.80 & -0.39 & 1 & & & & \\
\hline $\mathrm{Na}$ & 0.25 & 0.49 & 0.82 & 0.20 & 0.71 & 0.88 & -0.65 & 0.84 & 1 & & & \\
\hline $\mathrm{NO}_{3}$ & -0.40 & -0.55 & -0.47 & 0.029 & -0.59 & -0.55 & 0.31 & -0.61 & -0.64 & 1 & & \\
\hline $\mathrm{SiO}_{2}$ & $\begin{array}{l}-0.33 \\
\end{array}$ & 0.02 & -0.002 & 0.35 & -0.15 & 0.05 & -0.16 & $\begin{array}{l}-0.21 \\
\end{array}$ & -0.21 & 0.03 & 1 & \\
\hline Chl- $a$ & -0.53 & -0.36 & -0.42 & -0.44 & -0.33 & -0.52 & 0.53 & -0.30 & -0.52 & 0.31 & 0.12 & 1 \\
\hline
\end{tabular}

The phosphate value ranged from $0.16 \mu \mathrm{mol} \mathrm{L} \mathrm{L}^{-1}$ in Umra during September to 4.9 $\mu$ mol L $\mathrm{L}^{-1}$ in Umra during October (Fig. 2.g). The phosphate concentration was high during the monsoon period which ranges $3.7 \pm 1 \mu$ mol $\mathrm{L}^{-1}$. It shows a significant negative correlation with sulphate, Dissolved Oxygen and Salinity. The highest amount of phosphate was mostly found in fresh water receiving areas and lower in lower reaches. The upper reaches areas reported the highest phosphate content during monsoon month which might have be received through agricultural runoff and from cities. Moreover, release of phosphate from sediments due to stirring action by strong tidal waves could also be another causative factor. The observed variation might be caused by various processes like adsorption and desorption of phosphate and buffering action of sediments under varying environmental conditions [19].

The concentration of nitrate varied from $4.1 \mu \mathrm{mol} \mathrm{L} \mathrm{L}^{-1}$ in Hazira during July to 11.6 $\mu$ mol L $\mathrm{L}^{-1}$ in Cosway during September (Fig. 2.j). Nitrate shows significant negative correlation with $\mathrm{pH}$, Alkalinity, Salinity, Sodium and Potassium. The negative correlation between nitrate and salinity showed that freshwater influx, which is considered to be the main source of this nutrient in coastal waters [5, 29]. It also shows a strong positive correlation with phosphate. Variations in nitrate and its reduced inorganic compounds are predominantly the results of biologically activated reactions. Quick assimilation by phytoplankton and enhancement by surface runoff results in large scale spatio-temporal variation of nitrate in the coastal milieu [7, 24, 32]. During monsoon, the freshwater influx dilutes the coastal water resulting in decrease in salinity and increase in solubility of DO in the present study.

The amount of sodium was in the range $50 \mu \mathrm{mol} \mathrm{L}{ }^{-1}$ to $1495 \mu \mathrm{mol} \mathrm{L}^{-1}$ the highest been observed in Dumas in June and lowest in Cosway during September (Fig. 2.i). It shows significant positive correlation salinity, alkalinity and sulphate concentration and negatively correlated with Phosphate (-0.64). Potassium was in the range $25 \mu \mathrm{molL}^{-1}$ in Cosway during September to $190 \mu \mathrm{mol} \mathrm{L} \mathrm{L}^{-1}$ in Dumas in the month of June (Fig. 2.h). It shows a significant positive correlation with salinity, phosphate and sulphate. The distribution of Sodium and Potassium is directly influence by the fresh water runoff.

Silicate forms an important parameter of phytoplankton distribution and was in the range $181.5 \mu \mathrm{mol} \mathrm{L}{ }^{-1}$ to $573.9 \mu \mathrm{mol} \mathrm{L}{ }^{-1}$ (Fig. 1.k). The highest and lowest silicate value was reported in the Hazira region during April and October, respectively. Silicate shows negative correlation with temperature. The spatio-temporal variation of silicate in coastal water is influenced by several factors, more importantly the proportional physical mixing of seawater with fresh water [22], adsorption of reactive silicate into 
suspended sedimentary particles [13], chemical interaction with clay minerals [3,9] and biological removal by phytoplankton, especially by diatoms and silicoflagellates [14]. Silicate showed strong negative correlation with salinity and strong positive correlation with DO. [13] explained that the freshwater, which is rich in DO, could be the main source of silicate in this coastal water as entry of silicate into a coastal zone mainly takes place through land drainage rich with weathered silicate material.

In estuarine environment the primary productivity depends upon the phytoplankton, which alone contributes $\sim 90 \%$ of the total estuarine primary production. Thus, chl- $a$, which constitutes the chief photosynthetic pigment of phytoplankton, is an index that would provide the primary production potential upon which the biodiversity, biomass, and carrying capacity of that system depends upon. The chlorophyll $-\mathrm{a}$, value was observed high in the fresh water zone particularly in the post monsoon season and the value ranges from $0.16 \mu \mathrm{gm} \mathrm{L}^{-1}$ to $10.2 \mu \mathrm{gm} \mathrm{L}^{-1}$ (Fig. 2.l). The lowest been observed in Dumas during the month of June and highest in Cosway during the post monsoon and per summer seasons. Chlorophyll shows a significant negative correlation with temperature, sulphate and sodium. Relatively higher chl- $a$ values observed during March to May could be due the phytoplankton productivity in summer. A similar observation has been made from other coastal waters of India [15, 21, 27].

\section{Cluster Analysis}

Cluster analysis can be used an important tool for analysing water quality data $[1,28]$ to understand the relationship among stations and months. Month-wise water quality parameters formed three clusters (Fig.3). This indicated that the coastal water quality over a period of one year exert three clusters in different seasons. The first cluster was formed by the months from July, August, October and November. This showed that during the period of monsoon, the coastal water quality behaved alike. The second cluster was formed by the months from November, January, February and December, which corresponded to the period of winter. The third cluster formed by June, May, April and March is typically different from other periods due to high tidal influence.

DENDROGRAM

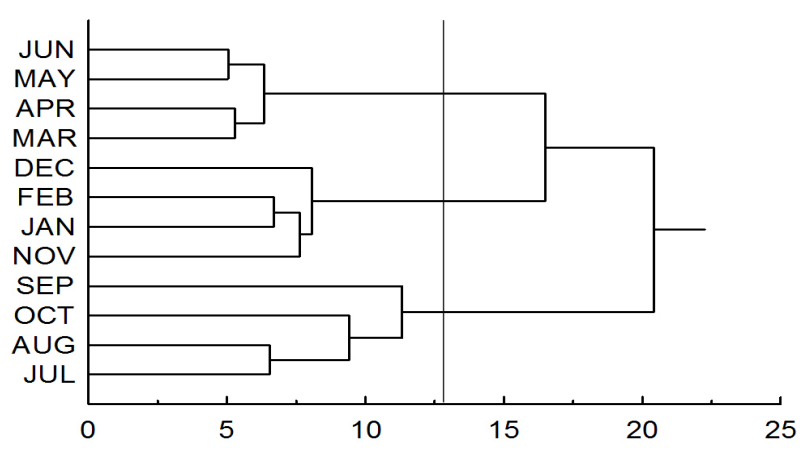

Figure 3. Month wise cluster diagram

The station-wise dendrogram showed two clusters (Fig. 4). The first cluster is formed by the fresh water dominant area in the upper reaches at site Dumas, SP Bridge and Umra which receives a continuous fresh water influx from July to February months. The second cluster is formed by the sites Hazira and Dumas which located on the lower 
reaches nearby to the mouth of the estuary. The similarity of tidal influence and low fresh water influence in the area accounts for the cluster formation. These two cluster formations are justified by the prevalence of different environmental conditions in the study sites.

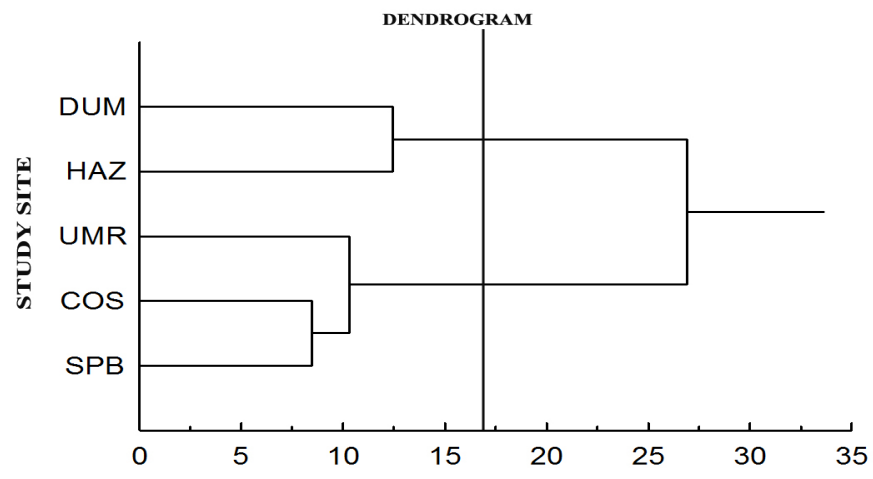

Figure 4. Site wise cluster diagram

\section{Principal Component Analysis}

The data obtained from the laboratory analysis were used as variables inputs for Principal Components Analysis (PCA), for water samples described by twelve physical, chemical and biological parameters which performed using the SPSS package. Prior to the analysis the data were standardized to produce a normally distribution of all variables, since water quality parameters had different magnitudes and scales of measurements, which if not taken into account would have given more weight to certain variables due to their respective variance [6]. From the standardized covariance or correlation matrix of the data the initial factor solution were extracted by the multivariate principal components extraction, then a number of PC were selected from the initial according to their Eigenvalues and scree diagram.

Table 3. Explaining Initial values

\begin{tabular}{|c|c|c|c|}
\hline \multicolumn{5}{|c|}{ Initial Eigenvalues } \\
\hline Components & Total & \% of Variance & Cumulative\% \\
\hline 1 & 5.82 & 48.5 & 48.5 \\
\hline 2 & 1.72 & 14.4 & 62.9 \\
\hline 3 & 1.45 & 12.1 & 74.9 \\
\hline 4 & 0.89 & 7.5 & 82.3 \\
\hline 5 & 0.66 & 5.5 & 87.9 \\
\hline 6 & 0.55 & 4.6 & 92.5 \\
\hline 7 & 0.28 & 2.3 & 94.8 \\
\hline 8 & 0.22 & 1.8 & 96.7 \\
\hline 9 & 0.19 & 1.5 & 98.2 \\
\hline 10 & 0.11 & 0.09 & 99.2 \\
\hline 11 & 0.05 & 0.04 & 99.6 \\
\hline 12 & 0.04 & 0.03 & 100 \\
\hline
\end{tabular}

This method aims to transform the observed variables to a new set of variables of principal components (PC) which are arranged in decreasing order of importance so that to simplify. Table 3. represented the determined initial Eigenvalues, its total, \% of variance and cumulative $\%$. 


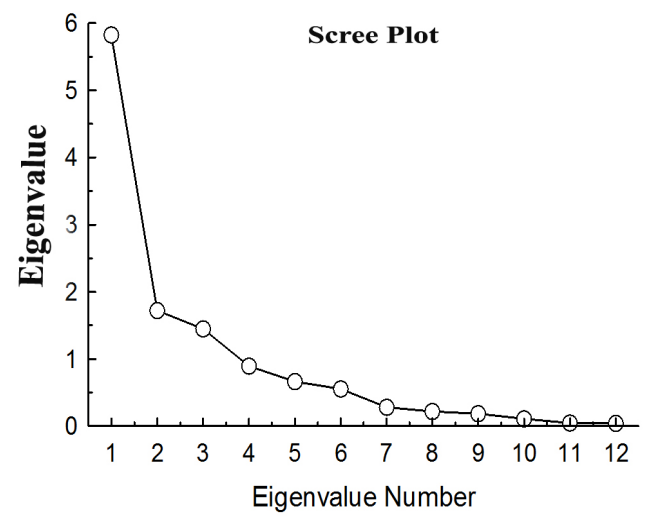

Figure 5. Scree plot graph for components with its Eigenvalues

Fig. 5 showed the scree plot of the eigenvalue for each component. Eigenvalues accounts and scree plot showed that the first three PC is the most significant components which represent more than $75 \%$ of the variance in water quality; in addition it has eigenvalue of more than one. PC1 accounts for $48.5 \%$ of the total variance, which is due to positive load of Salinity (0.364), Sulphate (0.387), Sodium (0.390) and Potassium (0.346) and negative load of Nitrate(-0.314), Phosphate (-0.346) and Chlorophyll-a(-0.269). Whereas PC 2 accounts for $14.4 \%$ of the total variance, which is due to positive load of DO (0.633) and Silicate (0.282) and negative load of Temperature (-0.443) and Phosphate (-0.434). While PC 3 accounts for $12.1 \%$ of the total variance, which is due to positive load of Silcate (0.502) and Chlorophyll-a (0.546) and negative load of Temperature (-0.436). (Table 4).

Table 4. Principal Component Analysis

\begin{tabular}{|l|c|c|c|}
\hline & PC1 & PC2 & PC3 \\
\hline Eigen Value & 5.822 & 1.722 & 1.447 \\
\hline Variability (\%) & 48.5 & 14.4 & 12.1 \\
\hline Cumulative (\%) & 48.5 & 62.9 & 74.9 \\
\hline Factor Loadings & & & -0.436 \\
\hline${ }^{\circ} \mathrm{C}$ & 0.150 & -0.443 & 0.058 \\
\hline $\mathrm{pH}$ & 0.261 & -0.159 & -0.286 \\
\hline $\mathrm{DO}$ & 0.105 & 0.633 & 0.155 \\
\hline Salinity & 0.364 & 0.090 & 0.227 \\
\hline Alkalinity & 0.280 & -0.126 & 0.111 \\
\hline Phosphate & -0.285 & -0.434 & 0.113 \\
\hline Sulphate & 0.387 & 0.132 & 0.208 \\
\hline Potassium & 0.346 & -0.192 & 0.085 \\
\hline Sodium & 0.389 & 0.013 & -0.157 \\
\hline Nitrate & -0.314 & 0.164 & 0.502 \\
\hline Silicate & -0.119 & 0.282 & 0.545 \\
\hline Chl- $a$ & -0.268 & -0.059 & \\
\hline
\end{tabular}

Components loading (correlation coefficients), which measure the degree of closeness between the variables and the PC, the largest loading either positive or negative, suggests the meaning of the dimensions; positive loading indicates that the contribution of the variables increases with the increasing loading in dimension; and negative loading indicates a decrease. 


\section{CONCLUSION}

The present study summarizes the seasonal fluctuations in various physico-chemical parameters in the waters of the Tapi estuary as exploratory statistical data output which showed that the physicochemical properties of the estuarine zone were significantly affected by freshwater input during monsoon. The highest concentration for all the nutrients and DO was observed during the monsoon; on the other hand, salinity and chl$a$ were at their minimum level during this period. The distribution of dissolved inorganic nutrients in this tropical coast may be very much influenced by factors like tidal and physical stirring by currents [4] and benthic invertebrates [11, 17] as well as drainage discharged from industries and cities around the estuarine zone. A significant increase in nitrate, phosphate, silicate, and turbidity and conversely, a decrease in DO and chl- $a$ concentration were noticed during the present study. Cluster analysis provides a clear variation in water quality, both station wise and month wise. The variability among different components was described by PCA and found that Principal component one; two and three are responsible much of the variation existed in the zone during the study period.

Acknowledgements: The authors are highly thankful to Ministry of Environment and Forest (MoEF), New Delhi for financial support.

\section{REFERENCES}

[1] Abbas Al-karkhi, F.M., Azmal Hossain, M.D., Norli, I. (2008): Application of Cluster Analysis for Water Quality Parameters, Juru Estuary (MALAYSIA) - International Conference on Environmental Research and Technology (ICERT 2008).

[2] APHA (1998): Standard Methods for the Examination of Water and Wastewater. (20th edition). Washington D.C - American Water Works Association/Water Env. Federation.

[3] Aston, S. R. (1980): Nutrients, dissolved gases and general bio-geochemistry of estuaries - In: Chemistry and biogeochemistry of estuaries, edited by Olausson, E. and Cato, I. John., Wiley and Sons Ltd: 233-257.

[4] Bowman, M.J. (1977): Nutrients distribution and transport in Long Island Sound. Journal of Estuarine and Coastal Marine Science 5: 53-54.

[5] Choudhary, S., Panigrahy, R.C. (1991): Seasonal distribution and behaviour of nutrients in the creek and coastal waters of Gopalpur east coast of India. - Mahasagar 24: 81-83.

[6] Davis, J.C. (1973): Statistics and data analysis in geology. - John Wiley and Sons, inc., New York.: 550.

[7] De Souza, S.N. (1983): Study on the behaviour of nutrients in the Mandovi estuary during premonsoon. - Estuarine, Coastal and Shelf Science 16: 299-308.

[8] Edward, P.J.K., Ayyakkanu, K. (1991): Studies on the Ecology of Plankton Community of Kollidam Estuary, Southeast Coast of India. - Mahasagar 24: 89-97.

[9] Gouda, R., Panigrahy, R.C. (1992): Seasonal distribution and behaviour of silicate in the Rushikulya estuary, East coast of India. - Indian Journal of Marine Sciences 24: 111-115.

[10] Granier, J., Billen, G., Palfner, L. (2000): Understanding the oxygen budget and related ecological processes in the river Mosel: The RIVERSTRAHLER approach. Hydrobiologia 410: 151-166.

[11] Hammond, D.E., Simpson H.J., Mathieu, G. (1977): Radon-222 distribution and transport across the sediment-water interface in the Hudson River estuary. - Journal of Geophysical Research, 82: 3913-3920. doi: 10.1029/JC082i027p03913.

[12] Jiyalalram, J.M. (1991): Algae and Water Pollution in Mahi Estuary. - Journal of Indian Fisheries Association. 21: 31-37. 
[13] Lal, D. (1978):Transfer of chemical species through estuaries to oceans. - In Proc. of UNESCO/SCOR workshop. Melreus, Belgium. 166-170.

[14] Liss, P.S., Spencer, C.P. (1970): A biological process in the removal of silicate from seawater. - Geochimica et Cosmochimica Acta, 34: 1073-1088.

[15] Madhupratap, M., Nair, K.N.V., Gopalakrishnan, T.C., Haridas, P., Nair, K.K.C., Venugopal, P., Gauns, M. (2001): Arabian Sea oceanography and fisheries off the west coast of India. - Current Science 81: 355-361.

[16] Martin, G.D., Vijay, J.G., Laluraj, C.M., Madhu, N.V., Joseph, M., Nair, G.V.M., Gupta, K.K., Balachandran. (2007): Fresh water influence on nutrient Stoichiometry in a tropical estuary, southwest coast of India. - Applied ecology and environm. research. 6(1): 57-64.

[17] McCaffery, R.J., Myers, A.C., Davey, E., Morrison, G., Bender, M., Luedtke, N., Culler, D., Froelich, P., Klinkhammer, G. (1980): The relation between pure water chemistry and benthic fluxes of nutrients and mangrove in Narragansett Bay, Rhode Island. Limnology and Oceanography 25: 31-44.

[18] Menon, N.N., Balchand, A.N., Menon, N.R. (2000): Hydrobiology of the Cochin backwater system - a review. - Hydrobiologia 430: 149-183.

[19] Pomeroy, C.R., Smith, E.E., Grant, C.M. (1965): The exchange of phosphate between estuarine water and sediments. - Limnology and Oceanography 10: 167-172.

[20] Pradhan U.K., Shirodkar, P.V, Sahu, B.K. (2009): Physico-chemical characteristics of the coastal water off Devi estuary, Orissa and evaluation of its seasonal changes using chemometric techniques. - Current Science 96: 1203-1209.

[21] Prasannakumar, S., Muralidharan, P.M., Prasad, T.G., Ganus, M., Ramaiah N., De Souza S.N., Sardesai S., Madhupratap, M. (2002): Why Bay of Bengal is less productive during summer monsoon compared to the Arabian Sea? - Geophys. Res. Letter 29: 88.1-88.4.

[22] Purushothaman, A., Venugopalan, V.K. (1972): Distribution of dissolved Silicon in the Vellar Estuary. - Indian Journal of Marine sciences 1: 103-105.

[23] Qasim, S.Z. (2003): Indian Estuaries. - Allied Publishers Pvt Ltd., New Delhi.

[24] Qasim, S.Z. (1977): Biological productivity of the Indian Ocean. - Indian Journal of Marine sciences 6: 122-137.

[25] Riley, J.P. Chester, R. (1971): An introduction to marine chemistry. - London: Academic.

[26] Sarala Devi, K., Sankaranarayanan, V.N., Venugopal, P. (1991): Distribution of nutrients in Periyar river estuary. - Indian Journal of Marine sciences 20: 49-54.

[27] Sarma, V.V., Sadhuram, Y., Sravanthi N.A., Tripathy, S.C. (2006): Role of physical processes in the distribution of chlorophyll-a in the Northwest Bay of Bengal during preand post-monsoon seasons. - Current Science 91: 1133-1134.

[28] Satpathy, K.K., Mohanty, A.K., Natesan,U., Prasad, M.V.R., Sarkar,S.K. (2009): Seasonal variation in physicochemical properties of coastal waters of Kalpakkam, east coast of India with special emphasis on nutrients. - Environmental Monitoring and Assessment. DOI 10.1007/s10661-009-0882-0.

[29] Satpathy, K.K. (1996): Seasonal distribution of nutrients in the coastal waters of Kalpakkam, east coast of India. - Indian Journal of Marine sciences 25: 221-224.

[30] Shyamalendu Bikash Saha, Bhattacharyya, S.B., Mitra, A., Pandey, B.K., Amalesh Choudhary (2001): Physicochemical characteristics in relation to pollution and phytoplankton production potential of a brackish water ecosystem of Sundarbans in West Bengal. - Tropical Ecology. 42(2): 199-205.

[31] Srinivas, K., Revichandran, C., Maheswaran P.A., Mohamed Ashraf, T.T., Nuncio, Murukesh (2003): Propagation of tides in the Cochin estuarine system, southwest coast of India. - Indian Journal of Marine sciences 32(1): 14-24.

[32] Zepp, R.G. (1997): Interactions of marine biogeochemical cycles and the photodegradation of dissolved organic carbon and dissolved organic nitrogen. - In: Gianguzza, A., Pelizzetti, E., Sammarkano, S. (Eds.) - Marine chemistry. London: Kluwer. 329-352. 